\title{
ЗДРАВЕТО НА МИГРАНТИТЕ И МАЛЦИНСТВАТА ВЪВ ФОКУСА НА СВЕТОВНОТО И ЕВРОПЕЙСКОТО ОБЩЕСТВЕНО ЗДРАВЕ
}

, $\boldsymbol{B}_{\text {бално }}$ М. Камбурова

бално политическо и хуманитарно безпокойство, както може би никога досега, Първият световен конгрес по миграция, етническа расова принадлежност и здраве (MERH) се фокусира върху здравните последици от движението и разнообразието на хората по света в рамките на широк исторически, политически, сочиален и екологичен контекст. " [2]

В периода 17-19 май 2018 г. в Единбург, Шотландия се проведе Първият световен конгрес по миграция, етническа, расова принадлежност и здраве. Конгресът беше организиран от секцията „Здраве на мигрантите и малцинствата“" на Европейската асоциация по обществено здраве (EUPHA).

Участие в Конгреса взеха над 700 участници от над 50 държави с единствена цел: насьрчаване на единството и споделяне на идеи чрез интегриран диалог по теми, свързани със здравето на мигрантите, етническото и расово разнообразие, както и предизвикателства по отношение на здравето на ромското население.

Като редовен член на секцията „Здраве на мигрантите и малцинствата““ представител за България на Конгреса бе доц. д-р Мариела Стефанова Камбурова. Нейните дългогодишни научни усилия по отношение на здравето на ромската общност в България бяха представени на Конгреса чрез доклад на тема „Health status of Roma population in small towns in Bulgaria“. [3] Научната разработка е в съавторство и е реализирана съвместно със студенти-медици от ромски произход, чиито ментор по време на обучението им в Медицинския университет - Плевен е доц. Камбурова.

Интересът на доц. Камбурова във връзка със специфичните здравни проблеми на мигрантите и малцинствата намира приложение в предлаганата от нея в Медицинския университет - Плевен новаторска за страната учебна програма „Здраве на мигрантите и малцинствата“ за студенти по обществено здраве. [1] По този начин факултет „Обществено здраве“ изпреварващо отговаря на отправения призив на приетото на Конгреса Становище на Европейската асоциация по обществено здраве по отношение на здравето на мигрантите и етническите малцинства. [5]

В Становището се подчертава, че „Мигрантите $u$ представителите на етническите маличинства (МЕМ) често изпитват сериозни неравенства както по отночение на тяхното здравословно състояние, така и по отношение на достъпа до качествени здравни услуги. Тези неравенства все по-често се извеждат наяве от изследователите в областта на общественото здравеопазване, но действията за преодоляването им изостават.“"Поставя се акцент върху следните ключови въпроси, които са разгледани по-подробно в Обяснителен меморандум. [4]

1. Необходимост от основани на доказателства политики за здравето на МЕМ.

а. Основни понятия и събиране на данни Необходимостта от повече валидни данни трябва да бъде първият приоритет в здравето на МЕМ.

б. Състоянието и детерминанти на здравето на МЕМ

в. Въпроси, свързани с предоставянето на здравни услуги. Взаимодействието между здравните служби и техните MEM потребители, включващо въпросите за достъпа, качеството, потреблението и комуникацията, се превърна в основна област на научните изследвания в рамките на EUPHA.
2. Целева група. Докато повечето международни организации насочват вниманието си главно към мигрантите, позицията на EUPHA винаги е била, че етническите малцинства, вкл. ромите, трябва също да бъдат обхванати.

3. Разнообразие на групите МЕМ. Свръхгенерализираните подходи, които не представят разнообразието в групите, трябва да бъдат заменени от „междусекторни” анализи, които едновременно разглеждат ефектите и взаимодействията на социално-икономическото положение, пол, възраст и други променливи.

4. Необходимост от по-широко определяне на миграцията. Притокът на неоторизирани лица в Европейския съюз (ЕС) през 2015-2016 г. (така наречената „мигрантска криза") доведе до едностранчив фокус върху потребностите на лицата, мигриращи принудително и нелегално, игнорирайки „рутинната” миграция.

5. Борба с фрагментирането на здравната политика за МЕМ в Европа. В допълнение към съществуващите разделения между европейските страни и езиковите общности, регионалните и международни организации често се конкурират помежду си, вместо да си сътрудничат, което води до загуба на усилия и възможности за сътрудничество.

6. Повишено внимание в изследователските програми на ЕС по отношение на здравето на MEM. EUPHА изразява загриженост относно липсата на внимание в тази програма по отношение на здравните неравенства като цяло и тези, които засягат в частност МЕM.

7. По-добро осигуряване на образование и обучение по отношение на здравето на МЕМ. Въпреки че Становището се отнася основно до връзките между научните изследвания и разработването на политики в областта на здравето на MEM, изграждането на капацитет в двете области трябва да бъде подкрепено от образование и обучение, насочено към всички здравни специалисти, изследователи, мениджъри и политици. То не трябва да се предоставя само в избираеми курсове, а да бъде част от основните учебни програми.

Представените основни моменти и Становището на Европейската асоциация по обществено здраве по отношение на здравето на мигрантите и етническите малцинства като цяло са в съответствие с Целите за устойчиво развитие на ООН. Чрез техния постулат „никой да не бъде изоставен” и акцентът им върху равенството във всички държави (не само в „развиващите се”) се предоставя положителна и категорична подкрепа за усилията в борбата с неравенствата по отношение на здравето на МЕM. [6]

\section{Библиография}

1. Камбурова М. “Здраве на мигрантите и малцинствата” - новаторска дисциплина в сферата на общественото здраве. Социална медицина, 2018, XXVI, №1, 24-26.

2. Krasnik, A., R.S. Bhopal, L. Gruer, S. K. Kumanyika. Advancing a unified, global effort to address health disadvantages associated with migration, ethnicity and race. European Journal of Public Health, Volume 28, Issue suppl_1, 1 May 2018, cky046, https://doi.org/10.1093/eurpub/cky046

3. Kamburova M., M Sandova, P Karadzhova, D Asenova, S Georgieva. Health status of Roma population in small towns in Bulgaria. European J of Public Health, v.28, 1, 2018, https://doi.org/10.1093/eurpub/cky048.250 4. https://bit.ly/2KN66jV

5. http://www.merhcongress.com/wp-content/uploads/2018/05/EUPHA-statement-on-migrant-and-ethnic-minority-health1.pdf

6. https://sustainabledevelopment.un.org/

\section{Aвтор}

Доц. д-р Мариела Камбурова, дм, МУ-Плевен, Факултет „Обществено здраве“, e-mail: mariela_kamburova@уahoo.com 